\title{
Effect of Different Intake Levels of Dietary Protein and Physical Exercise on Bone Mineral Density and Bone Strength in Growing Male Rats
}

\author{
Satoko TAKEDA ${ }^{1}$, Yuki KobAYASHI ${ }^{1}$, Jong-Hoon PARK ${ }^{1,2}$, Ikuko EZAWA ${ }^{3}$ and Naomi OMI ${ }^{1,4, *}$ \\ ${ }^{1}$ Graduate School of Comprehensive Human Sciences, University of Tsukuba, Ibaraki 305-8574, Japan \\ ${ }^{2}$ Center for Disease Biology and Integrative Medicine, University of Tokyo, Tokyo 113-0033, Japan \\ ${ }^{3}$ Japan Women's University, Tokyo 112-8681, Japan \\ ${ }^{4}$ Faculty of Health and Sport Sciences, University of Tsukuba, Ibaraki 305-8574, Japan
}

(Received January 30, 2012)

\begin{abstract}
Summary Having higher bone mineral density (BMD) during growth is complexly influenced by many factors. For example, nutrition and physical exercise are key factors. However, few studies have investigated the combined effects of these factors. In this study, we investigated the effect of physical exercise and different levels of protein intake on BMD and bone strength of growing male rats. Forty-seven male Wistar rats ( 5 wk old) were randomized into 10\% (Low), 20\% (Moderate) and 40\% (High) protein diet groups, and each group was further divided into exercise groups (LEx, MEx, HEx) or non-exercise groups (L, M, H). Exercise group rats were trained $6 \mathrm{~d}$ per week on a treadmill $(25-30 \mathrm{~m} / \mathrm{min}, 60 \mathrm{~min})$ for $60 \mathrm{~d}$. After being sacrificed, their BMD and bone strength were evaluated. The BMD of tibia, femoral breaking force and energy were significantly lower in the low protein diet groups than the other diet groups. In particular, the femoral breaking energy was significantly lower in the HEx group than in the $\mathrm{H}$ group, while there were no differences between LEx and L or MEx and M. Taken together, our data suggests that a low protein intake could suppress acquisition of bone mass and increasing bone strength during growth. Moreover, a high protein intake could also suppress bone strength during growth in which physical activity was vigorously performed. Therefore, sustaining an adequate protein intake level, around $20 \%$ protein intake, may be of significance for increasing not only bone mass but bone strength during growth.
\end{abstract}

Key Words bone mineral density, protein, physical exercise, growing phase

It is generally well accepted that physical activity is important for having higher bone mineral density (BMD) during growth (1). Bone mass or strength is closely associated with the risk of fracture. A higher peak bone mass, defined as the highest level of BMD or bone mineral content (BMC) reached during life, could reduce the fracture risk.

In addition to physical activity, various nutritional factors complexly influence growth of bone mass. In particular, protein, a component of bone matrix, is essential for increasing bone mass and strength. An adequate protein intake is positively related to sufficient BMD or BMC during the growth period (2). Protein deficiency could decrease the secretion of insulinlike growth factor 1 (IGF-1) (3), which may prevent normal growth of bone mass. Moreover, the negative effect of a low protein intake was seen in the growth of tibial length in growing male rats when participating in physical exercise (4). Conversely, a high protein intake results in higher urinary calcium (Ca) excretion, which may lead to accelerated bone resorption (5). Although the harmful effect of a high protein intake on bone mass

\footnotetext{
*To whom correspondence should be addressed.

E-mail: ominaomi@taiiku.tsukuba.ac.jp
}

during growth has not been reported before, it is possible that a high protein intake would have a negative effect on bone mass. Among growing individuals in Japan, dietary protein intake seems to be higher than the usual recommended dietary allowance $(6,7)$. In particular, although people involved in physical training have high protein intakes $(8,9)$, few studies have investigated the effects of different levels of protein intake and physical exercise on BMD or bone strength. Ribeiro et al. (4) demonstrated that when combined with swimming exercise, a high protein intake of $28 \%$ did not have an additional effect on tibial length compared with a moderate protein intake of $21 \%$ in growing rats. However, they did not investigate the effect of loading stress on BMD or bone strength.

Accordingly, in this study, we investigated the effect of different levels of protein intake and running exercise on BMD and bone strength in growing male rats. The purpose of this study was to acquire knowledge about nutrition and physical exercise for increasing bone mass or bone strength during growth.

\section{MATERIALS AND METHODS}

Experimental animals and protocol. Forty-seven male Wistar rats, $5 \mathrm{wk}$ of age were obtained from CLEA 
Table 1. Composition of experimental diets.

\begin{tabular}{|c|c|c|c|}
\hline \multirow{2}{*}{ Constituents } & Law protein & Moderate protein & High protein \\
\hline & $(0.6 \% \mathrm{Ca}, 0.6 \% \mathrm{P})$ & $(0.6 \% \mathrm{Ca}, 0.6 \% \mathrm{P})$ & $(6 \% \mathrm{Ca}, 0.6 \% \mathrm{P})$ \\
\hline Glucose monohydrate & 70.2 & 60.4 & 40.8 \\
\hline Casein (vitami-free) & 10.0 & 20.0 & 40.0 \\
\hline Cystine & 0.2 & 0.2 & 0.2 \\
\hline Cottonseed oil & 10.0 & 10.0 & 10.0 \\
\hline $\mathrm{CaCO}_{3}$ & 1.4932 & 1.4879 & 1.4774 \\
\hline $\mathrm{KH}_{2} \mathrm{PO}_{4}$ & 1.2304 & 1.1424 & 0.9666 \\
\hline $\mathrm{K}_{2} \mathrm{HPO}_{4}$ & 1.5748 & 1.4621 & 1.2372 \\
\hline Cellulose pawder ${ }^{\mathrm{a}}$ & 3.0 & 3.0 & 3.0 \\
\hline Choline chloride & 0.2 & 0.2 & 0.2 \\
\hline Water soluble vitamin mixture ${ }^{b}$ & 0.1 & 0.1 & 0.1 \\
\hline Oil soluble vitamin mixture & $\mathrm{c}$ & $\mathrm{c}$ & $\mathrm{c}$ \\
\hline Ca.P free salt mixture ${ }^{\mathrm{d}}$ & 2.0 & 2.0 & 2.0 \\
\hline Energy (kcal/100 g) & 367 & 374 & 387 \\
\hline PFC balance $(\mathrm{P} / \mathrm{F} / \mathrm{C})(\%)$ & $11 / 25 / 64$ & $21 / 25 / 54$ & $40 / 25 / 35$ \\
\hline Calcium (in \%) & 0.61 & 0.57 & 0.58 \\
\hline Phosphorus (in \%) & 0.74 & 0.71 & 0.72 \\
\hline
\end{tabular}

\footnotetext{
a ADVANTEC Cellulose Powder, no. 49020040.

${ }^{b}$ The water soluble vitamin mixture (in \%): thiamine, 0.5 ; riboflavin, 0.5; pyridoxine, 0.5 ; calcium pantothenate, 2.8; nicotinamide, 2.0; inositol, 20.0; foric acid, 0.02; vitamin B12, 0.002; biotin, 0.01; and glucose monohydrate, 3.7.

${ }^{\mathrm{c}}$ The rats received a supplement of fat-soluble vitamin in cotton seed oil three times a week which was supplied with $70 \mu \mathrm{g}$ of $\beta$-carotene, $105 \mu \mathrm{g}$ of 2-methyl-1,4-naphthoquinone, $875 \mu \mathrm{g}$ of $\alpha$-tocopherol and 525 I.U. of vitamin D3.

$\mathrm{d}$ The calcium (Ca) phosphorus (P) free salt mixture (in \%): potassium chloride, 57.7; sodium chloride, 20.9; magnesium sulfate, anhydrous, 17.9; copper (II) sulfate pentahydrate, 0.078; sodium fluoride, 0.113; cobalt (II) chloride, 0.004; potassium lodide, 0.01; magnese (II) sulfate pentahydrate, 0.06; hexaammonium heptamolybdate tetrahydrate, 0.005; iron (II) sulfate heptahydrate, 3.22; zinc sulfate heptahydrate, 0.44 .
}

Japan, Inc. (Tokyo, Japan). Rats were randomized into the $10 \%$ protein (Low protein intake), 20\% protein (Moderate protein intake) and 40\% protein (High protein intake) groups. Each group was further divided into exercise groups (LEx, Low protein intake with exercise; MEx, Moderate protein intake with exercise; HEx, High protein intake with exercise) or non-exercise groups (L, Low protein intake with non-exercise; M, Moderate protein intake with non-exercise; $\mathrm{H}$, High protein intake with non-exercise). The experimental period was $11 \mathrm{wk}$. The animals were individually housed at $23 \pm 1{ }^{\circ} \mathrm{C}$ and humidity of $50 \pm 5 \%$, on an inverted $12 / 12 \mathrm{~h}$ light/dark cycle. All animals received food and water ad libitum. Body weight and food intake were measured at $48 \mathrm{~h}$ intervals throughout the experimental period. All experimental protocols in the present study were approved by the Committee on Animal Research at the University of Tsukuba.

Experimental diets. Each group received a different level of protein in its diet, $10 \%, 20 \%$, or $40 \%$ of diet weight. The recommended dietary percentage of protein for growing animals is $17.9 \%$ (10), so we used $10 \%$ protein as a low protein intake, $20 \%$ protein as a moderate protein intake, and $40 \%$ protein as a high protein intake. In all three diets, calcium (Ca) and phosphorus (P) contents were identical. These diets were controlled $0.6 \%$ (Ca) and $0.6 \%(\mathrm{P})$. The diet composition is described in Table 1. Each diet was burnt to ash at $600^{\circ} \mathrm{C}$ for $15 \mathrm{~h}$ in the electronic furnace (Hi-temp Oven, DR200, Yamamoto Inc, Tokyo), and the resulting ash was dissolved in $1 \mathrm{~N}$ nitric acid. Ca concentration was measured by Inductively Coupled Plasma Atomic Emission Spectroscopy (ICAP-AES-575v Nippon Jarrell-Ash, Japan). P was measured by the Fisk-SubbaRow method (11).

Exercise. Exercise group rats were trained $6 \mathrm{~d}$ per week on a treadmill (KN-73, Natsume, Tokyo). The running speed and time were gradually increased (10$25 \mathrm{~m} / \mathrm{min}, 10-60 \mathrm{~min})$. Regular training started on the 17 th day, and the running speed was increased even more $(25-30 \mathrm{~m} / \mathrm{min})$. Finally, the rats ran for 60 consecutive minutes $(27-30 \mathrm{~m} / \mathrm{min})$. The training period was $60 \mathrm{~d}$. This running speed $(30 \mathrm{~m} / \mathrm{min})$ corresponds to $60-70 \% \mathrm{VO}_{2} \max$ for rats (12). To this training was added a warm-up session ( $15 \mathrm{~m} / \mathrm{min}, 5 \mathrm{~min})$ and a cooldown session $(15 \mathrm{~m} / \mathrm{min}, 5 \mathrm{~min})$, for a total exercise time of $70 \mathrm{~min}$.

Dissection. After $11 \mathrm{wk}$ (16 wk of age), rats were fasted for $12 \mathrm{~h}$ and dissected. The femur and tibia were collected, and cleaned of adjacent tissues. The femora were immediately measured for length, and stored at $4^{\circ} \mathrm{C}$ for later mechanical testing. The tibiae were stored in $70 \%$ ethanol for the bone mineral density assessment. In addition, skeletal muscles (quandriceps femoris, soleus, gastrocnemius, and plantaris) and abdominal fat were removed, and the wet tissue weights were measured. 
Table 2. Final body weight, body weight gain, food intake, energy intake and food efficiency.

A)

\begin{tabular}{|c|c|c|c|}
\hline & \multicolumn{3}{|c|}{ Diet group } \\
\hline & Low & Moderate & High \\
\hline \multicolumn{4}{|c|}{ Initial body weight (g) } \\
\hline $\operatorname{Ex}(-)$ & $157.0 \pm 1.76$ & $159.1 \pm 1.55$ & $159.3 \pm 1.27$ \\
\hline $\operatorname{Ex}(+)$ & $157.8 \pm 1.73$ & $155.8 \pm 1.69$ & $155.8 \pm 2.12$ \\
\hline \multicolumn{4}{|c|}{ Final body weight (g) } \\
\hline $\operatorname{Ex}(-)$ & $399.8 \pm 8.65^{\mathrm{b}}$ & $455.5 \pm 12.74^{\mathrm{a}}$ & $435.8 \pm 7.68^{\mathrm{a}}$ \\
\hline $\operatorname{Ex}(+)$ & $334.3 \pm 5.50^{c}$ & $350.0 \pm 7.55^{\mathrm{c}}$ & $359.8 \pm 6.81^{\mathrm{c}}$ \\
\hline \multicolumn{4}{|c|}{ Body weight gain $(\mathrm{g} / \mathrm{d})$} \\
\hline $\operatorname{Ex}(-)$ & $3.53 \pm 0.10^{\mathrm{b}}$ & $4.30 \pm 0.15^{\mathrm{a}}$ & $4.05 \pm 0.10^{\mathrm{a}}$ \\
\hline $\mathrm{Ex}(+)$ & $2.77 \pm 0.06^{\mathrm{c}}$ & $2.92 \pm 0.05^{\mathrm{c}}$ & $3.07 \pm 0.09^{c}$ \\
\hline \multicolumn{4}{|c|}{ Lower leg muscle (g/100 g BW) } \\
\hline $\operatorname{Ex}(-)$ & $0.611 \pm 0.019$ & $0.588 \pm 0.020$ & $0.599 \pm 0.019$ \\
\hline $\operatorname{Ex}(+)$ & $0.654 \pm 0.012$ & $0.597 \pm 0.104$ & $0.683 \pm 0.028$ \\
\hline \multicolumn{4}{|c|}{ Abdominal fat $(\mathrm{g} / 100 \mathrm{~g} \mathrm{BW})$} \\
\hline $\operatorname{Ex}(-)$ & $5.975 \pm 0.006^{\#}$ & $7.501 \pm 0.239$ & $6.167 \pm 0.495^{\#}$ \\
\hline $\operatorname{Ex}(+)$ & $3.123 \pm 0.004^{* \#}$ & $4.237 \pm 0.293^{*}$ & $3.803 \pm 0.235^{\text {*\# }}$ \\
\hline \multicolumn{4}{|c|}{ Food intake $(\mathrm{g} / \mathrm{d})$} \\
\hline $\operatorname{Ex}(-)$ & $17.93 \pm 0.34^{\mathrm{a}}$ & $18.76 \pm 0.44^{\mathrm{a}}$ & $16.77 \pm 0.28^{\mathrm{b}}$ \\
\hline $\operatorname{Ex}(+)$ & $15.34 \pm 0.22^{\mathrm{c}}$ & $15.20 \pm 0.22^{\mathrm{c}}$ & $15.06 \pm 0.26^{c}$ \\
\hline \multicolumn{4}{|c|}{ Energy intake (kcal/d) } \\
\hline $\operatorname{Ex}(-)$ & $66 \pm 1^{b}$ & $70 \pm 2^{\mathrm{a}}$ & $65 \pm 1^{b}$ \\
\hline $\operatorname{Ex}(+)$ & $56 \pm 1^{c}$ & $57 \pm 1^{\mathrm{c}}$ & $58 \pm 1^{\mathrm{c}}$ \\
\hline \multicolumn{4}{|c|}{ Food efficiency ${ }^{1}$} \\
\hline $\operatorname{Ex}(-)$ & $0.22 \pm 0.00^{\mathrm{a}}$ & $0.23 \pm 0.01^{\mathrm{a}}$ & $0.27 \pm 0.01^{b}$ \\
\hline $\operatorname{Ex}(+)$ & $0.20 \pm 0.00^{c}$ & $0.19 \pm 0.00^{c}$ & $0.23 \pm 0.00^{\mathrm{d}}$ \\
\hline
\end{tabular}

B)

\begin{tabular}{lccc}
\hline & & Two-way ANOVA \\
\cline { 2 - 4 } & Exercise & Protein & Exercise $\times$ Protein \\
\hline Initial body weight $(\mathrm{g})$ & $\mathrm{ns}$ & $\mathrm{ns}$ & $\mathrm{ns}$ \\
Final body weight $(\mathrm{g})$ & 0.000 & 0.000 & 0.038 \\
Body weight gain $(\mathrm{g} / \mathrm{d})$ & 0.000 & 0.000 & 0.008 \\
Lower leg muscles $(\mathrm{g} / 100 \mathrm{~g} \mathrm{BW})$ & $\mathrm{ns}$ & $\mathrm{ns}$ & $\mathrm{ns}$ \\
Abdominal fat $(\mathrm{g} / 100 \mathrm{~g} \mathrm{BW})$ & 0.000 & 0.000 & $\mathrm{~ns}$ \\
Food intake $(\mathrm{g} / \mathrm{d})$ & 0.000 & 0.001 & 0.008 \\
Energy intake $(\mathrm{kcal} / \mathrm{d})$ & 0.000 & 0.046 & 0.004 \\
Food efficiency & 0.000 & 0.000 & 0.005
\end{tabular}

A) ${ }^{1}$ Food efficiency was caluculated by Body weight gain $(\mathrm{g} / \mathrm{d}) /$ Food intake $(\mathrm{g} / \mathrm{d})$.

$\operatorname{Ex}(-)$ : non exercise group, $\mathrm{EX}(+)$ : exercise group. Values are expressed as means $\pm \mathrm{SE}$.

* Significantly different from the Ex $(-)$ group. ${ }^{\#}$ Significantly different from the moderate protein group. ${ }^{\text {a-d }}$ Significantly difference between groups for a given variable (mean values with unlike superscript were significantly different, $p<0.05$ ).

B) Data were analyzed by two-way ANOVA at the 5\% level of significance. Exercise $\times$ Protein means interaction. "ns" indicates not significant.

Bone mineral density. The BMC and area of whole tibiae were analyzed, and the BMD was calculated based on these data by dual-energy X-ray absorptiometry (DXA: Aloka DCS-600R) (13).

Femoral weights and mechanical testing. Femoral length was measured with a precision caliper. The femoral breaking force and energy were measured by the three point bending method using a bone strength measuring apparatus (Iio Co., Japan) as described in a previous report (14). Subsequently, the femora were dried at $100^{\circ} \mathrm{C}$ for $24 \mathrm{~h}$ in the electric furnace, and we measured the dry weight. Next, the dried femora were turned to ash at $600^{\circ} \mathrm{C}$ for $15 \mathrm{~h}$, and we measured the ash weight. The data of femoral breaking force and energy were adjusted to the dry weight (the adjusted breaking force and energy) to exclude the influence of body mass.

Statistical methods. The results are expressed as the mean \pm standard error of the mean (SE) and were analyzed with SPSS (version $12.0 \mathrm{~J}$; SPSS Inc., Chicago, IL, USA). The data were analyzed using a two-way analysis 
A)

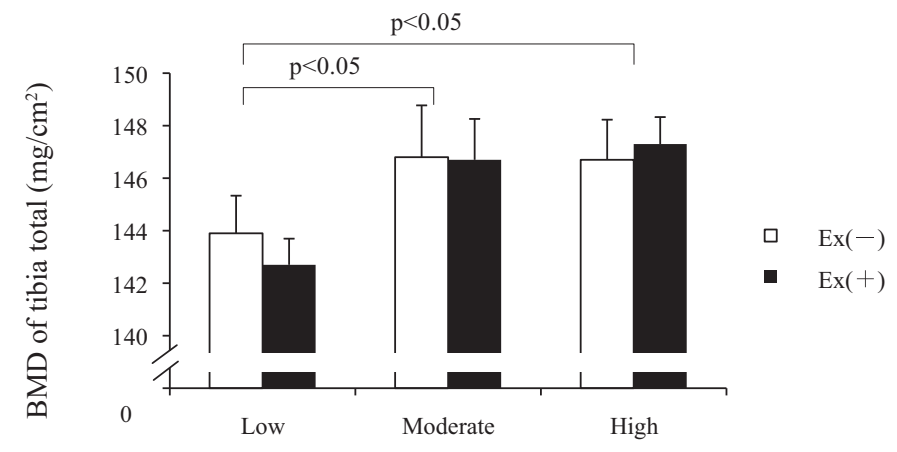

B)

\begin{tabular}{lccc}
\hline & \multicolumn{3}{c}{ Two-way ANOVA } \\
\cline { 2 - 4 } & Exercise & Protein & Exercise $\times$ Protein \\
\hline BMD & ns & 0.015 & ns \\
Tibia Total $(\mathrm{mg})$ & & & \\
\hline
\end{tabular}

Fig. 1. Bone mineral density of tibia total. A) The tibia of each rat was isolated by dissection, and the muscle and connective tissue were carefully removed. BMD was then measured by dual-energy X-ray absorptiometry. Vertical bars indicate the standard error. $p$ value indicates statistical significant difference among dietary protein groups. B) Data were analyzed by two-way ANOVA at the $5 \%$ level of significance. Exercise $\times$ Protein means interaction. "ns" indicates not significant.

A)
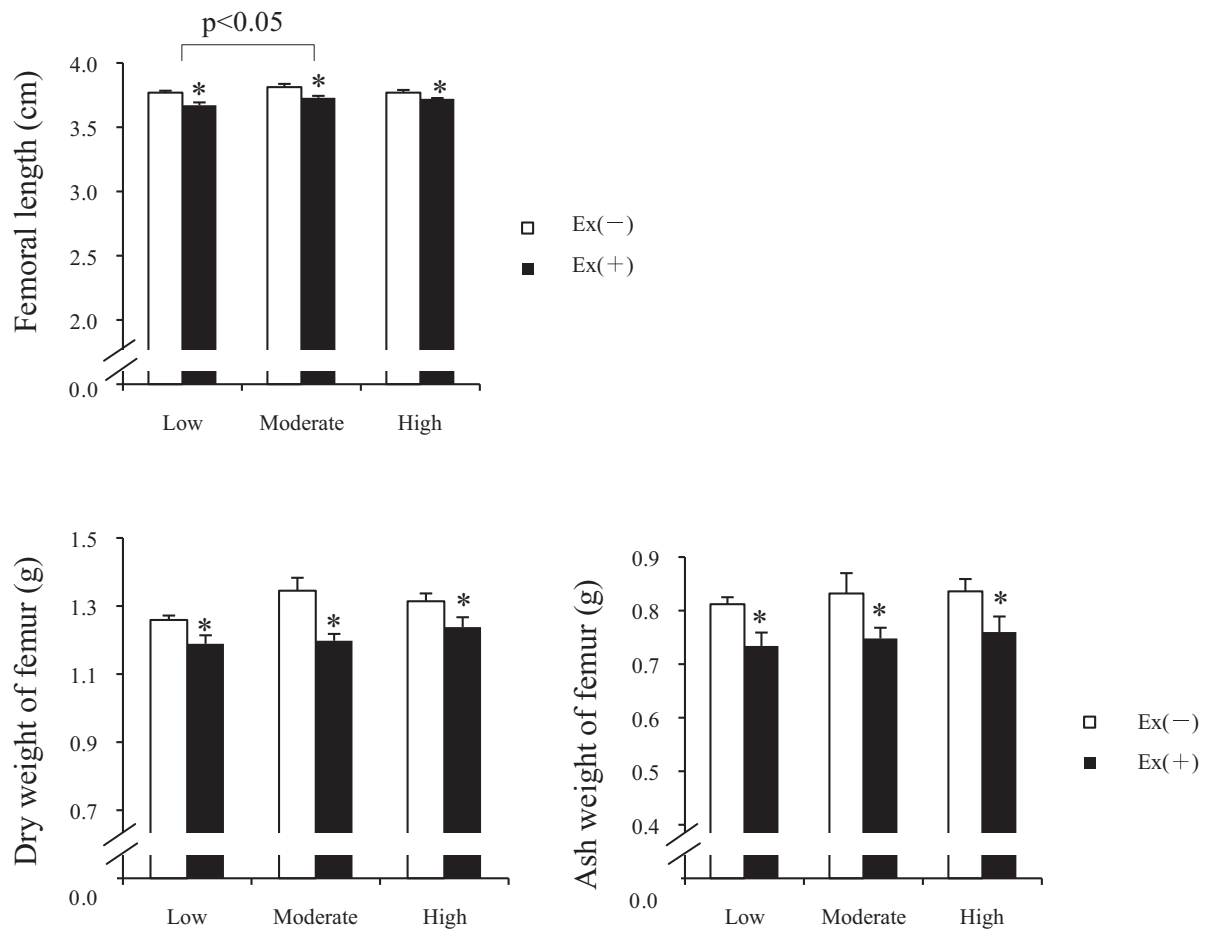

B)

\begin{tabular}{lccc}
\hline & \multicolumn{3}{c}{ Two-way ANOVA } \\
\cline { 2 - 4 } & Exercise & Protein & Exercise $\times$ Protein \\
\hline Femoral length (cm) & 0.000 & 0.019 & $\mathrm{~ns}$ \\
Dry weight of femur (g) & 0.000 & $\mathrm{~ns}$ & $\mathrm{~ns}$ \\
Ash weight of femur (g) & 0.000 & $\mathrm{~ns}$ & $\mathrm{~ns}$ \\
& & & \\
\hline
\end{tabular}

Fig. 2. Bone characteristics. A) Vertical bars indicate the standard error. $p$ value indicates statistical significant difference among dietary protein groups. * Significantly different from the Ex(-) group. B) Data were analyzed by two-way ANOVA at the 5\% level of significance. Exercise $\times$ Protein means interaction. "ns" indicates not significant. 
Table 3. Breaking force and energy of the femoral diaphysis.

A)

\begin{tabular}{|c|c|c|c|}
\hline & \multicolumn{3}{|c|}{ Diet group } \\
\hline & Low & Moderate & High \\
\hline \multicolumn{4}{|c|}{ Breaking force $\left(\times 10^{6}\right.$ dyn $)$} \\
\hline $\operatorname{Ex}(-)$ & $23.375 \pm 1.052^{\# \$}$ & $28.185 \pm 1.656$ & $29.871 \pm 0.926$ \\
\hline $\operatorname{Ex}(+)$ & $21.963 \pm 0.987^{* \# \$}$ & $26.593 \pm 1.094^{*}$ & $25.710 \pm 1.164^{*}$ \\
\hline \multicolumn{4}{|c|}{ Adjusted breaking force $\left(\times 10^{6} \mathrm{dyn} / \text { dry wt. }\right)^{1}$} \\
\hline $\operatorname{Ex}(-)$ & $37.233 \pm 1.431^{\mathrm{c}}$ & $41.905 \pm 1.475^{\mathrm{a}}$ & $45.503 \pm 1.005^{\mathrm{a}}$ \\
\hline $\operatorname{Ex}(+)$ & $38.780 \pm 1.463^{\mathrm{c}}$ & $44.414 \pm 1.243^{\mathrm{ab}}$ & $41.418 \pm 1.293^{\mathrm{b}}$ \\
\hline \multicolumn{4}{|c|}{ Breaking energy $\left(\times 10^{5} \mathrm{erg}\right)$} \\
\hline $\operatorname{Ex}(-)$ & $17.937 \pm 0.956^{\mathrm{c}}$ & $23.618 \pm 2.247^{\mathrm{a}}$ & $22.116 \pm 1.231^{\mathrm{a}}$ \\
\hline $\operatorname{Ex}(+)$ & $16.276 \pm 2.195^{\mathrm{c}}$ & $26.391 \pm 0.805^{\mathrm{a}}$ & $18.729 \pm 1.310^{\mathrm{b}}$ \\
\hline \multicolumn{4}{|c|}{ Adjusted breaking energy $\left(\times 10^{5} \text { erg/dry wt. }\right)^{1}$} \\
\hline $\operatorname{Ex}(-)$ & $28.507 \pm 1.295^{c}$ & $36.598 \pm 2.096^{\mathrm{b}}$ & $33.528 \pm 1.564^{\mathrm{b}}$ \\
\hline $\operatorname{Ex}(+)$ & $28.112 \pm 1.863^{\mathrm{c}}$ & $44.093 \pm 0.903^{\mathrm{a}}$ & $30.059 \pm 1.315^{\mathrm{bc}}$ \\
\hline
\end{tabular}

B)

\begin{tabular}{lccc}
\hline & & Two-way ANOVA \\
\cline { 2 - 4 } & Exercise & Protein & Exercise $\times$ Protein \\
\hline Breaking force $\left(\times 10^{6} \mathrm{dyn}\right)$ & 0.004 & 0.000 & $\mathrm{~ns}$ \\
Adjusted breaking force $\left(\times 10^{6}\right.$ dyn/dry wt. $)$ & 0.000 & 0.009 & 0.019 \\
Breaking energy $\left(\times 10^{5} \mathrm{erg}\right)$ & $\mathrm{ns}$ & 0.000 & 0.038 \\
Adjusted breaking energy $\left(\times 10^{5} \mathrm{erg} /\right.$ dry wt. $)$ & 0.000 & 0.000 & 0.000 \\
\hline
\end{tabular}

A) * Significantly different from the $\operatorname{Ex}(-)$ group. ${ }^{\#}$ Significantly different from the moderate protein group. ${ }^{\$}$ Significantly different from the high protein group. ${ }^{\mathrm{a}-\mathrm{c}}$ Significantly difference between groups for a given variable (mean values with unlike superscript were significantly different, $p<0.05$ ).

${ }^{1}$ Breaking force and energy adjusted to the dry weight.

B) Data were analyzed by two-way ANOVA at the 5\% level of significance. Exercise $\times$ Protein means interaction. "ns" indicates not significant.

of variance (ANOVA). If a significant interaction was detected, the post hoc Bonferroni test was employed for all multiple comparisons. If a significant interaction was not detected, the post hoc Tukey test was employed for multiple comparisons among the exercise groups and the diet groups. Statistical significance was accepted at the $p<0.05$ level.

\section{RESULTS}

Food intake and body weight

At the beginning of the experiment, body weight did not differ among the groups. At the end of the experimental period, the food intake was significantly lower in the LEx, MEx, and HEx groups than that in the L, M, and $\mathrm{H}$ groups, respectively $(p<0.001)$. Therefore, the final body weight was significantly lower in the exercise groups than in the non-exercise groups, respectively $(p<0.001)$. Among the non-exercise groups, the food intake was significantly lower in the $\mathrm{H}$ group than in the $\mathrm{L}$ and $\mathrm{M}$ groups $(p<0.05$ and $p<0.001$, respectively). Moreover, the final body weight was significantly lower in the L group than in the $\mathrm{M}$ and $\mathrm{H}$ groups $(p<0.001)$, whereas there were no differences among exercise groups (Table 2). Two-way ANOVA revealed the interactions between exercise and dietary protein in final body weight $(p<0.05)$, body weight gain $(p<0.01)$, food intake $(p<0.01)$, energy intake $(p<0.01)$, and food efficiency $(p<0.01)$.

On the other hand, the lower leg muscles (soleus, gastrocnemius, and plantaris) were not significantly different among any groups. In the weights of abdominal fat/100 g body weight, the exercise effect $(p<0.001)$ was noted, with lower values in the exercise groups (Table 2 ). The moderate protein diet groups showed higher values when compared to the low protein diet groups $(p<0.001)$ or the high protein diet groups $(p<0.05)$. $B M D$

Dietary protein effects were obtained in the BMD of tibia $(p<0.05)$, and were significantly lower in the low protein diet groups than the other diets $(p<0.05)$ (Fig. 1).

\section{Bone characteristics}

In femoral length, exercise and dietary protein effects were obtained $(p<0.001$ for exercise; $p<0.05$ for dietary protein). The femoral length was significantly lower in the exercise groups than in the non-exercise groups. It was also significantly lower in the low protein diet groups than the moderate protein groups $(p<0.05)$. On 
the other hand, only exercise effect was obtained in the dry weight and ash weight of femur $(p<0.001)$. The dry weight and ash weight of femur were significantly lower in the exercise groups than in the non-exercise groups (Fig. 2).

Bone breaking force and energy

A significant interaction (exercise $\times$ dietary protein) was detected for femoral breaking energy $(p<0.05)$, whereas not for femoral breaking force. Dietary protein effect was obtained in femoral breaking force $(p<0.001)$ and the low protein groups were significantly lower than the other diet groups (Table 3). The femoral breaking energy was also significantly lower in the low protein diet groups than the other diet groups $(p<0.001)$ (Table 3). In particular, the femoral breaking energy was significantly lower in the HEx group than in the $\mathrm{H}$ group $(p<0.05)$, whereas there were no differences between LEx and L or MEx and M groups. A significant interaction (exercise $\times$ dietary protein) was detected for the adjusted breaking force and energy $(p<0.05$ and $p<0.001$, respectively). The adjusted breaking force was significantly lower in the HEx group than in the H group $(p<0.05)$, whereas there were no differences between the LEx and L or the MEx and M groups. In particular, the adjusted breaking energy was significantly higher in the MEx group than in the M group or other exercise groups $(p<0.01)$, although there were no differences between the LEx and L or the HEx and H groups.

\section{DISCUSSION}

We investigated the effects of different levels of protein intake and physical exercise on BMD and bone strength in growing male rats. This study demonstrated that a low protein intake suppressed acquisition of bone mass and increasing bone strength during growth periods. In particular, a high protein intake suppressed increasing bone strength during growth in which physical activity was vigorously performed.

In the present study, we showed the effect of different levels of protein intake in the BMD of tibia. Prior research reported that a low protein intake during growth induced a lower BMD (15). This supports our result that the BMD of the tibia was significantly lower in the low protein diet groups than in the other diet groups. On the other hand, there was no difference among the moderate protein diet groups or the high protein diet groups. A cross-sectional study among elderly women showed a positive relation between protein consumption and bone mass (16); more positive bone status was observed among participants with protein intakes of $>87 \mathrm{~g} / \mathrm{d}$ (nearly $80 \%$ above the dietary reference value of protein in the USA) than those with protein intakes of $<66 \mathrm{~g} / \mathrm{d}$. However, our result showed a different effect of a high protein diet on the BMD of tibia during the growth phase. Therefore, the effect of a high protein intake on bone mass may differ according to age, so more studies in growing models are necessary.

Consistent with the results of $\mathrm{BMD}$, the low protein intake was absolutely shown to have a detrimental effect on the bone strength. Interestingly, the harmful effect of physical exercise was observed on the femoral breaking energy in the high protein group, while not shown on the BMD. Although voluntary wheel running (17), jumping (18), treadmill running (19) have demonstrated the beneficial effects of increased load on bone mass or mechanical properties of the femur, tibia, and humerus, the effects of physical exercise were not similar among the different levels of protein intake in our study. Seventy percent of bone strength depends on its density and $30 \%$ depends on its quality (20). The bone quality is determined by the degree of bone mineralization, microdamage accumulation, bone size, collagen crosslinks formation and bone turnover rate (21). Thus, the reason for the lower bone breaking energy in the HEx group than in the $\mathrm{H}$ group might be the bone quality. Ribeiro et al. (4) reported that an increase in dietary protein $(28 \%)$ for growing rats when combined with swimming exercise could not increase bone length or muscle weight. Moreover, in adults, the effect of chronic acid load caused by a high protein intake can induce bone resorption (22). Taken together, these results suggest that a high protein intake might make it difficult to add to the positive effect on bone mass or bone turnover during a growth phase. It should be noted that although Chevalley et al. (2) reported that in physically active prepubertal boys, even protein intakes above the median were associated with greater bone mass gain in various skeletal sites, this observation was not taken as a scientific basis to consider excessive protein intakes for children. So we have not reached a close consensus on the effect of a high protein intake on BMD or bone strength compared with the study results of Chevalley et al. (2) in prepubertal boys.

Physical exercise and the amount of dietary intake strongly influence the change of body mass, which strongly affects the bone mass status $(23,24)$. In the present study, the exercise groups had lower food intakes despite the expenditure of physical activity-related energy, which may have led to lower final body weight and femoral dry weights compared with the non-exercise groups (Fig. 2). Thus, the status of energy balance might have been different between the exercise and non-exercise groups. Accordingly, we tried to analyze the femoral breaking force and energy followed by the adjustment to the dry weight to exclude the influence of body mass. As a result, the adjusted femoral breaking force was also significantly lower in the HEx group than in the $\mathrm{H}$ group, and in contrast, the adjusted femoral breaking energy was significantly higher in the MEx group than in the LEx or HEx group. These results, at least in part, support the fragility of bone strength in the high protein intake group combined with physical exercise. However, to clarify the effects of a high protein intake on bone mass or strength when performing physical activity in detail, it would have been important to add pair-feeding groups with non-exercise to the present experimental setting.

Our study had several limitations. The final body weight was significantly lower in the exercise groups than in the non-exercise groups. As mentioned above, 
growth of bone is considerably influenced by body mass. In fact, femoral length, dry weights of femur, and femoral breaking force were significantly lower in the exercise groups than in the non-exercise groups. Therefore, we were not unable to adequately describe the relation of age-related growth and benefits of physical exercise.

In summary, the present study demonstrated that a low protein intake, half of the $20 \%$ moderate protein intake, suppressed acquisition of bone mass and increasing bone strength during growth periods. On the other hand, a high protein intake, two times the $20 \%$ moderate protein intake, was not seen to have a better effect on bone mass or strength compared with a moderate protein intake. In particular, a high protein intake did not further promote the effect of physical exercise on bone mass or strength, although a moderate protein intake combined with the exercise were seen to have an additional effect on bone strength. Our data suggest that sustaining a moderate protein intake level in the diet, around a $20 \%$ protein level, may be of significance for obtaining higher bone mass and bone strength in growing rats.

\section{Acknowledgments}

The authors are grateful to all of the members of the Exercise and Nutrition Laboratory at the University of Tsukuba for their kind cooperation in the anatomy work. J. H. Park is supported by Japan Society for the Promotion of Science (JSPS). The authors have no relevant financial interest in this study.

\section{REFERENCES}

1) Hind K, Burrows M. 2007. Weight-bearing exercise and bone mineral accrual in children and adolescents: a review of controlled trials. Bone 40: 14-27.

2) Chevalley T, Bonjour JP, Ferrari S, Rizzoli R. 2008. Highprotein intake enhances the positive impact of physical activity on BMC in prepubertal boys. J Bone Miner Res 23: 131-142.

3) Yahya ZA, Bates PC, Millward DJ. 1990. Responses to protein deficiency of plasma and tissue insulinlike growth factor-I levels and proteoglycan synthesis rates in rat skeletal muscle and bone. J Endocrinol 127: 497-503.

4) Ribeiro SML, Rogero MM, Bacurau RFP, Campos PL, Luz SS, Lancna Jr AH, Tirapegui J. 2010. Effects of different levels of protein intake and physical training on growth and nutritional status of young rats. J Nutr Sci Vitaminol 56: $177-184$.

5) Jenkins DJ, Kendall CW, Vidgen E, Augustin LS, Parker T, Faulkner D, Vieth R, Vandenbroucke AC, Josse RG. 2003. Effect of high vegetable protein diets on urinary calcium loss in middle-aged men and women. Eur J Clin Nutr 57: 376-382.

6) MHLW. 2010. National health and nutrition and nutrition examination survey. Ministry of Health, Labour and Walfare [Online]. Available: http:// www.mhlw.go.jp/stf/houdou/2r9852000000xtwqimg/2r9852000000xu2r.pdf [accessed January 25, 2012].

7) Ministry of Health, Labour and Walfare. 2010. Dietary
Reference Intakes for Japanese, 2009. Dai-ichi Shuppan, Tokyo.

8) Carlsohn A, Cassel M, Linne K, Mayer F. 2011. How much is too much? A case report of nutritional supplement use of a high-performance athlete. Br J Nutr 25: $1-5$.

9) Penteado VS, Castro CH, Pinheiro Mde M, Santana M, Bertolino S, de Mello MT, Szejnfeld VL. 2010. Diet, body composition, and bone mass in well-trained cyclists. J Clin Densitom 13: 43-50.

10) Reeves PG, Nielsen FH, Fahey GC Jr. 1993. AIN-93 purified diets for laboratory rodents: final report of the American Institute of Nutrition ad hoc writing committee on the reformulation of the AIN-76A rodent diet. J Nutr 123: 1939-1951.

11) Fiske CH, SubbaRow Y. 1925. The calorimetric determination of phosphorus. J Biol Chem 66: 375-400.

12) Wheeler DL, Graves JE, Miller GL, Vander-Griend RE, Wronski TJ, Powers SK, Park HM. 1995. Effects of running in the torisional strength, morphometry, and bone mass of the rat skeleton. Med Sci Sports Exerc 27: $520-529$.

13) Omi N, Tsukahara N, Ezawa I. 2001. Effect of milk on bone metabolism in growing male and female rats. $J$ Home Econ Jpn 52: 689-698.

14) Ezawa I, Okada R, Nozaki Y, Ogata E. 1979. Breakingproperties and ash contents of the femur of growing rat fed a low calcium diet. J Jpn Soc Food Nutr 32: 329-335.

15) Kerstetter JE, Looker AC, Insogna KL. 2000. Low dietary protein and low bone density. Calcif Tissue Int 66: 313.

16) Devine A, Dick IM, Islam AF, Dhaliwal SS, Prince RL. 2005. Protein consumption is an important predictor of lower limb bone mass in elderly women. Am J Clin Nutr 81: 1423-1428.

17) Newhall KM, Rodnick KJ, van der Meulen MC, Carter DR, Marcus R. 1991. Effects of voluntary exercise on bone mineral content in rats. J Bone Miner Res 6: 289-296.

18) Notomi T, Lee SJ, Okimoto N, Okazaki Y, Takamoto T, Nakamura T, Suzuki M. 2000. Effects of resistance exercise training on mass, strength, and turnover of bone in growing rats. Eur J Appl Physiol 82: 268-274.

19) Peng Z, Tuukkanen J, Vaananen HK. 1994. Exercise can provide protection against bone loss and prevent the decrease in mechanical strength of femoral neck in ovariectomized rats. J Bone Miner Res 9: 1559-1564.

20) NIH Consensus Development Panel. 2001. Osteoporosis prevention, diagnosis, and therapy. JAMA $\mathbf{2 8 5}$ : 785-795.

21) Saito M, Fujii K, Marumo K. 2006. Degree of mineralization-related collagen crosslinking in the femoral neck cancellous bone in cases of hip fracture and controls. Calcif Tissue Int 79: 160-168.

22) Barzel US. 1976. Acid-induced osteoporosis: An experimental model of human osteoporosis. Calcif Tissue Res 21: 417-422.

23) El Hage R, El Hage Z, Jacob C, Moussa E, Theunynck D, Baddoura R. 2011. Bone mineral content and density in overweight and control adolescent boys. J Clin Densitom 14: 122-128.

24) El Hage R, Jacob C, Moussa E, Groussard C, Pineau JC, Benhamou CL, Jaffre C. 2009. Influence of the weight status on bone mineral content and bone mineral density in a group of lebanese adolescent girls. Joint Bone Spine 76: 680-684. 